G. Sokol, P. Podhornyi, A. Mishenko, R. Piskovyi, D. Herasymov

National University "Yuri Kondratyuk Poltava Polytechnic", Poltava, Ukraine

\title{
PROSPECTS FOR THE USE OF MIMO BASED ON IEEE 802.11ac IN IOT TECHNOLOGIES
}

\begin{abstract}
Over time, the requirements on the network and the level of Internet traffic become more demanding. From standard cable connection with a speed of $100 \mathrm{Mbps}$ to the use of Wi-Fi at speeds up to $2.3 \mathrm{Gbps}$ per channel $160 \mathrm{MHz}$ (802.11ac2) with simultaneous provision of multiple input mode - multiple output with multiple users (Multi User Multiple Input Multiple Output, MU-MIMO). In addition, the introduction of $5 \mathrm{G}$ mobile communication systems has significantly increased the level of mobile internet traffic. The development of the next generation of $6 \mathrm{G}$ with speeds from $100 \mathrm{Gbps}$ to 1 Tbit / s has already begun in the world when controlling the artificial intelligence network, which is planned for 2026-30. In its perspective, the expansion of the range of services based on cloud computing has given a significant impetus to the development of new areas of Internet use. As a result, various concepts based on the Internet of Things (IoT) are being rapidly implemented. As you know, this approach allows you to connect to the Internet any object equipped with sensors or sensors that can receive, transmit and process information, as well as apply different actions depending on the information received. The quality of examples can include "smart home", "smart city" and others. Implementation of communication between objects of opportunities via the Internet using Bluetooth, Wi-Fi, ZigBee, etc. Another, quite new direction is the concept of the Internet of BioNanoThings (IoBNT). As you know, a living cell is already a kind of nanomachine that is controlled by a genetic program. The cell's nucleus is the processor and memory, the mitochondria are the batteries, and the receptor proteins on the cell's surface are sensors that can receive signals, and their slit contacts with other cells can send signals. It only remains to reprogram them for your needs. At the same time, it is necessary to organize communication not only between the cells themselves, but also with the Internet. The cell can transmit bitwise information depending on the state, but at a very low speed. One of the options for implementing communications may be MIMO.
\end{abstract}

Keywords : Internet, Internet of Things, Internet of Bio-Nano things, MIMO, Wi-Fi, QAM.

\section{Introduction}

The Internet is a worldwide system of interconnected networks based on the use of Internet protocols. The Internet consists of a large number of local, global, private, public, academic, business, and government networks interconnected by wired, optical, and wireless technologies. The Internet is the basis for hosting large amounts of information and providing services such as interconnected hypertext documents, e-mail and others.

Modern networks are created on a multilevel basis. Transmission of information in the form of a sequence of bits starting from the level of communication lines and equipment. In turn, communication lines are of different quality. Then comes the level of basic software that controls the operation of the equipment. The next level is the software level, it provides basic software with various additional features. Expanding the functionality of networks by combining levels leads to the fact that you get a very useful and convenient tool.

IoT is a network of interconnected devices that have built-in transmitters and related software that allow them to exchange data between computer systems and the physical world using standard communication protocols. In addition to transmitters, the network can use embedded physical devices and interconnected through wired and wireless networks. Things have the ability to read and activate, the function of programming and identification, and the ability to exclude human participation, through the use of intelligent interfaces.

The term Internet of Things (IoT) was proposed in 1999 by Kevin Ashton, co-founder of the Auto-ID Research Center at the Massachusetts Institute of Technology. And in the same year, a research center was established, which began to deal with radio frequency identi- fication (RFID) and sensor technology. Due to these areas, this concept has become widespread.

The Internet of Things is becoming quite a popular topic of discussion in both work and everyday life. The concept of directly connecting the device you need to the Internet or another device, including mobile phones, portable devices, coffee makers, headphones, washing machines, lamps and anything else that can come to mind. Also for machine components, a jet engine or even an oil rig. A Gartner analyst said that by 2020 , the number of connected devices could reach more than 26 billion. The interaction will take place in pairs of people-things, people-people, and things-things.

The term Internet of Everything (IoE) is also becoming widespread.

The idea of the Internet of Things is quite simple. In general, the Internet of Things can be described as a symbolic formula:

«IoT $=$ Sensors + Data + Networks + Services».

That is, the Internet of Things is a global network made up of computers, actuators and sensors that communicate with each other using Internet protocols such as IP. The concept of IoT plays an important role in the development of information and communication technologies. IoT technology is based on three basic principles: a widespread communication infrastructure, global identification of each object and the ability of each object to exchange data via the local or global Internet to which it will be connected.

Nano-technologies have led to the development of devices that can range in size from one to hundreds of nanometers. In turn, these nano-machines consist of nano-components and are separate functional units that are able to perform measuring, regulating and control operations. 
The properties of recently studied nanomaterials, such as graphene, have inspired the concept of the Internet of NanoThings (IoNT), based on the interconnection of nanoscale devices. Nanotechnology is the miniaturization and manufacture of devices in the scale from 1 to $100 \mathrm{~nm}$. The prefix nano means one billionth (1x10-9). Nanotechnology is "a branch of technology that manufactures objects smaller than $100 \mathrm{~nm}$ and manipulates individual molecules and atoms." Nanomachines are full-featured devices and are capable to perform trivial tasks. Single nanomachines are capable to perform only trivial tasks, so to perform more complex tasks they must be interconnected to form an Internet of Nano things proposed as the basis for many future applications, such as in the military, health and security fields, where nanotubes, due to their small size, can be easily hidden, implanted and scattered in the environment, where they can jointly perform sounding, operation, processing and networking.

In addition to connecting different devices, Internet of Things technology already has its smoothing, such as The Internet of Bio-Nano things (IoBNT).

Nanoting, like other devices, are artificial in nature because they are based on synthesized materials, electronic circuits and interact through electromagnetic (EM) communications. Although the artificial nature of Nano Internet devices is a favorable factor for many applications, these characteristics can be detrimental to some environments, such as inside the body or in natural ecosystems, where the deployment of nanotubes and their EM radiation can lead to undesirable effects on health or pollution. A new line of research in the field of IoBNT engineering, nanoscale devices and systems, is carried out in the field of biology by combining nanotechnology with synthetic biology tools for control, reuse, modification and reengineering of biological cells. IoBNT serves as a paradigm-changing concept for communication and network engineering, where there are new challenges for developing effective and secure methods for information exchange, interaction and networking within biochemistry, while allowing Internet connection, communication used for communication between nanomachines. Based on the analogy between a biological cell and a typical embedded computing device IoT, the cell can be effectively used as a substrate for the implementation of bio-nano-things, by controlling, reusing and reengineering the functionality of biological cells such as probing, operation, calculation, storage and communication. Because cells are based on biological molecules and biochemical reactions rather than electronics, the concept of the Internet of bionanotinning is based on DNA, biochemical data processing, chemical energy conversion, and information exchange through the transmission and reception of molecules called Molecular Communication (MC, Molecular Communication) (Fig. 1).

$\mathrm{MC}$ is a paradigm in nanocommunication networks that use molecules to communicate between nanomachines. Molecular communication is biologically inspired, ie it adapts the communication mechanisms that already exist in nature, for communication between living organisms. The human body consists of a large- scale heterogeneous network in which molecular communication takes place. A living cell is already a kind of nanomachine that is controlled by a genetic program. The cell's nucleus is the processor and memory, the mitochondria are the batteries, and the receptor proteins on the cell's surface are sensors that can receive signals, and their slit contacts with other cells can send signals.

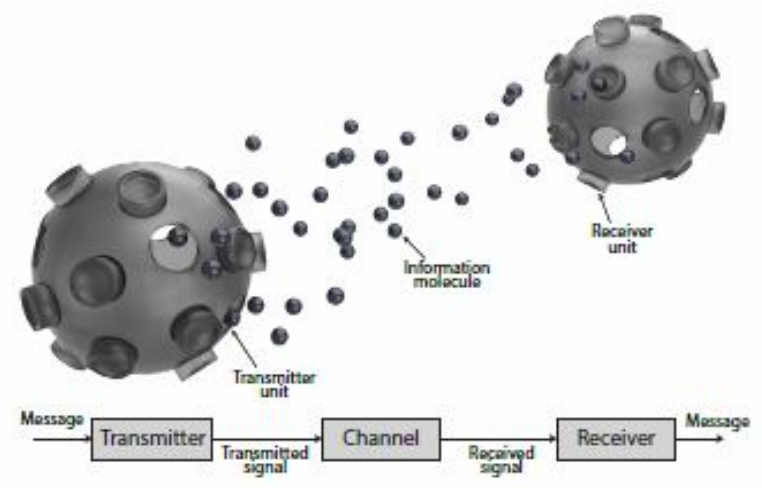

Fig. 1. MC between a pair of nanomachines

The scientific community is currently studying various aspects of MS communication and networking. MS is based on many applications that will be included in IoBNT:

- internal probing and activation of the body, where Bio-NanoThings inside the human body will jointly collect health-related information, transmit it to an external health care provider over the Internet, and execute commands from a single provider such as drug synthesis and release.

- internal connection, where Bio-NanoThings restores or prevents failures in communication between our internal organs, for example, based on the endocrine and nervous systems that underlie many diseases.

- Environmental control and purification: where Bio-NanoThings deployed in the environment, such as a natural ecosystem, will check for toxic and contaminants, and jointly transform these agents by bioremediation, such as bacteria used to clean up oil spills.

The Internet of Things is an open paradigm, extremely receptive and adaptable to new architectures and principles. In this regard, it can be extremely useful to use the principles and methods of cognition, by creating a cognitive Internet of Things (CIoT).

Cognitiveness, the presence of certain properties in an IoT object, such as:

- the ability to self-analysis and readjustment taking into account the existing environment, also aiming to achieve certain goals, which are due to the tasks performed;

- ability to adapt to existing conditions or events, based on certain knowledge of previous states;

- the ability to dynamically change its topology and operating parameters in accordance with user requirements, as part of the service policy, bandwidth optimization or other indicators;

- self-configuration;

- the ability to independently determine their current state and taking it into account - to plan their work, making certain decisions according to the situation. 
It is assumed that cognitive Internet of Things will be able to:

- obtain and use knowledge of their operational and geographical environment and location. For example, using GPS technology;

- set yourself or use ready-made rules of interaction between other objects (Internet things);

- dynamically or autonomously adjust their parameters and protocols in accordance with the acquired knowledge to apply them in the tasks, for example, to choose the technology of radio signal transmission;

- learn on their own based on the results achieved using the best and most effective policies to achieve the goals of IoT.

Interaction with the Internet of things occurs in several ways, depending on the software and hardware:

- direct access;

- access through the gateway;

- access through the server.

In the case of direct access, Internet of Things have their own IP address or network alias, which can be used to connect to them from any client application, and they must perform the functions of a web server. The interface with such Internet things is usually made in the form of a web-resource with a certain graphical interface for management through a web-browser.

If the Internet of Things does not have built-in support for IP and HTTP protocols, but only supports private protocols, Bluetooth or ZigBee, you need to use a special Internet gateway to interact with them. And the third form of interaction - through the server, ie the presence of an intermediary between the Internet of Things and the user and can be implemented through an intermediary platform. This approach requires a centralized server or multiple servers, the main tasks of which include:

- receiving messages from sensors of Internet of Things and their subsequent transmission to users;

- storage and processing of received information;

- providing an interface for the user with the possibility of duplex exchange between the user and the Internet thing.

The advent of wireless networks such as Wi-Fi, using the IEEE 802.11 standard, has attracted the attention of mankind. The networks were quickly and well received due to the low price and quite good indicators of agility and reliability. Due to the increase in transmitted traffic in the network posed some difficulties to, at that time, implemented technologies and standards and forced to improve the technical characteristics of devices and new methods of modulation and signal transmission. The new $802.11 \mathrm{~b}, 802.11 \mathrm{a}$ standards, which provided a fivefold increase in transmission speed, and now the universal $802.11 \mathrm{~g}$, which provides approximately 54 Mbps at $2.4 \mathrm{GHz}$.

802.11ac technology only works on Wi-Fi frequencies of $5 \mathrm{GHz}$. Therefore, dual-band access points often continue to use $801.11 \mathrm{n}$ at $2.4 \mathrm{GHz}$. But 802.11ac Wi-Fi clients operate in the less busy $5 \mathrm{GHz}$ frequency range.

Next, we present a network of working channels Wi-Fi and a frequency of $5 \mathrm{GHz}$ (Table 1).

To calculate the average frequency of a Wi-Fi channel you can use the following formula:

$$
\mathrm{F}_{\text {mid }}=5000+(5 \cdot \mathrm{N}) / \mathrm{MHz}
$$

where $\mathrm{N}$ is the Wi-Fi channel number, for example 36 (5180 MHz), 40 (5200 MHz), etc.

The formation of Wi-Fi channels at $5 \mathrm{GHz}$ is presented below in Fig. 2.

The distance from the limit bands is $30 \mathrm{MHz}$, and the inter-channel diversity is $20 \mathrm{MHz}$

Spatial Multiplexing (MIMO) - the use of several transmitting and receiving antennas. Unlike - MISO and SIMO, this option is aimed at increasing the transmission speed, rather than improving the reliability of the transmission. MIMO technology is widely used for data transmission to mobile stations, in good radio conditions, while MISO and SIMO are used for data transmission to stations in poor radio conditions. To increase the data rate in MIMO, the input stream is divided into several data streams, which are independently transmitted from individual antennas (Fig. 3).

\section{Table 1 - Network of working channels Wi-Fi and a frequency of $5 \mathbf{G H z}$}

\begin{tabular}{|c|c|c|c|c|c|c|c|c|c|c|c|c|c|c|c|}
\hline \multicolumn{3}{|c|}{ Chanel } & 36 & 40 & & 44 & 48 & & & & & & & & \\
\hline \multicolumn{2}{|c|}{$\begin{array}{l}\text { Midle frequency, } \\
\mathrm{MHz}\end{array}$} & & 5180 & 520 & & 220 & 5240 & & & & & & & & \\
\hline \multicolumn{2}{|c|}{ Radio band } & \multicolumn{6}{|c|}{ UNII-1 } & & & & & & & & \\
\hline Chanel & 52 & 56 & 60 & 64 & 100 & 104 & 108 & 112 & 116 & 120 & 124 & 128 & 132 & 136 & 140 \\
\hline $\begin{array}{l}\text { Midle } \\
\text { frequency, } \\
\mathrm{MHz}\end{array}$ & 5260 & 5280 & 5300 & 5320 & 5500 & 5520 & 5540 & 5560 & 5580 & 5600 & 5620 & 5640 & 5660 & 5680 & 5700 \\
\hline Radio band & \multicolumn{15}{|c|}{ UNII-2 } \\
\hline \multicolumn{2}{|c|}{ Chanel } & & 49 & 153 & 15 & & 161 & & & & & & & & \\
\hline \multicolumn{2}{|c|}{$\begin{array}{l}\text { Midle frequency, } \\
\mathrm{MHz}\end{array}$} & & 745 & 5765 & 578 & & 5805 & & & & & & & & \\
\hline \multicolumn{2}{|c|}{ Radio band } & \multicolumn{6}{|c|}{ UNNII-3 } & & & & & & & & \\
\hline
\end{tabular}

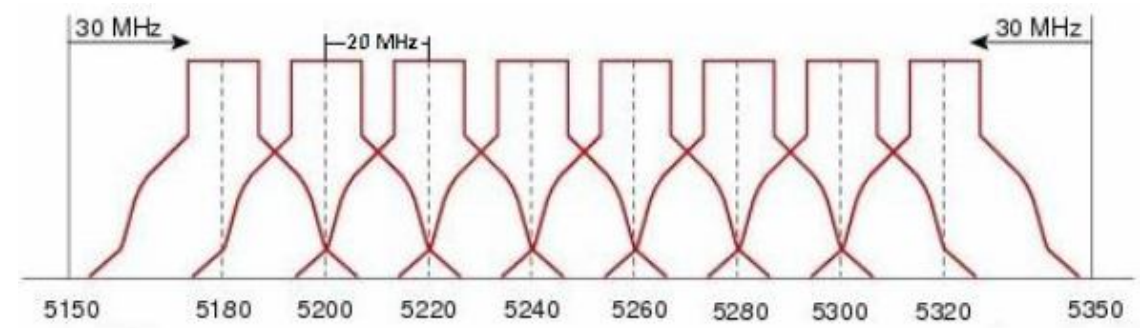

Fig. 2. Formation of Wi-Fi channels in $5 \mathrm{GHz}$ 


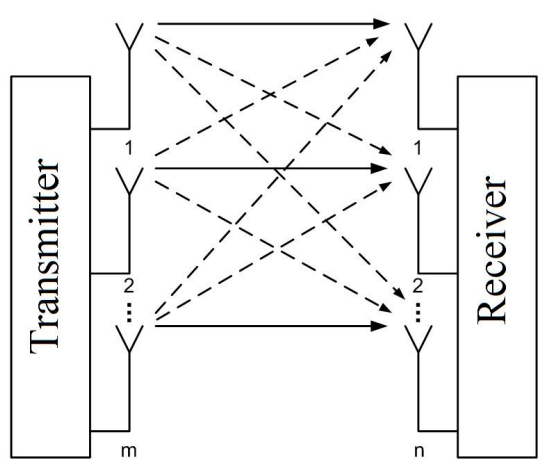

Fig. 3. Generalized scheme of MIMO

Through the use of a common channel, each antenna of the receiving side receives a signal not only intended for it, but also signals from other antennas. In general, the effect of signals, other antennas, can be calculated and minimized in the presence of a transmission matrix. The number of data streams that are transmitted simultaneously depends on the number of antennas used. With the same number of transmitting and receiving antennas, the number of data streams is equal to or less than the number of antennas. In the case of MIMO $4 \times 4$, the number of data streams can be 4 or less. If the number of receiving and transmitting antennas are different, then the number of independent data streams is equal to the minimum number of antennas or less. As an example, in MIMO $4 \times 2$ the number of streams can be 2 and less. To calculate the maximum bandwidth, the formula is:

$$
\mathrm{C}=\mathrm{M} \mathrm{B} \log 2(1+\mathrm{S} / \mathrm{N}) \text {, }
$$

where $\mathrm{C}$ is the bandwidth of the channel; $\mathrm{M}$ is the number of independent data streams; B - channel width; S / $\mathrm{N}$ - signal / noise ratio. Depending on the number of users to whom data is transmitted simultaneously, the following types are distinguished:

- Single User MIMO (SU-MIMO) - MIMO technology for data transmission to one user - all data streams are addressed to one user.

- Multi User MIMO (MU-MIMO) - MIMO for data transmission to multiple users simultaneously in the same resource blocks, all independent data streams are addressed to different users. In Fig. 4 an example of a MU-MIMO with two users is shown.

The first generation (First Wave) of WiFi 802.11ac (Wave-1) devices used half-duplex radio technology. Such devices typically use frequency channels up to $80 \mathrm{MHz}$ wide and often up to three spatial streams. Therefore, with a relatively rough distribution, we can indicate a low level of 802.11ac products with speeds in the radio channel up to $433 \mathrm{Mbps}$, an average level with speeds up to $867 \mathrm{Mbps}$ and a high level with speeds up to $1.3 \mathrm{Gbps}$.

Virtually available speeds for users will be much lower due to the overall efficiency of the 802.11 standards group. As a rule, a maximum of $60 \%$ is practically available.

The second generation of 802.11 ac products supports frequency channels up to $160 \mathrm{MHz}$ up to four spatial streams and simultaneous communication technology with more than one MU-MIMO (Multi User MIMO) user.

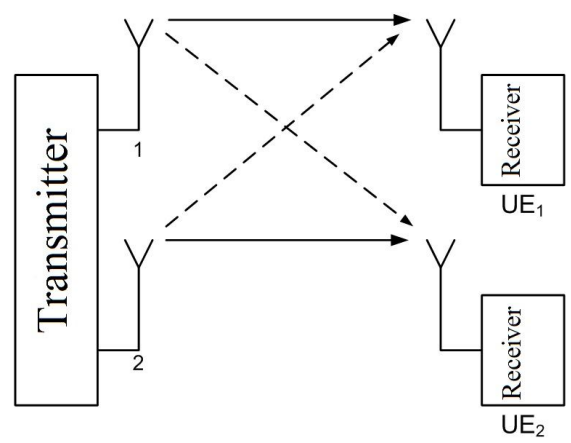

Fig. 4. MU-MIMO with two users

MU-MIMO allows you to send multiple frames simultaneously to many users in the same frequency spectrum. Thus, with multiple antennas and with the help of appropriate technology, the access point can behave as a wireless switch. But the technology is limited from above by the maximum number of available spatial streams. Hence, in the case of three supported spatial streams on the access point and only three client streams (MacBook Pro, for example), only one client will interact with the point, even with MU-MIMO support. Therefore, MU-MIMO looks especially promising for the case when the network is mainly personal mobile devices, such as smartphones and tablets, which have a maximum of 2 spatial streams, but most often one. For the case of smartphones with one thread and point with three threads and MU-MIMO, we will have a case of one to three operation, and point will support up to three clients simultaneously and in parallel.

The second wave of the WiFi 802.11ac standard (Wave-2) is characterized by access points with speeds in the radio channel up to $3.47 \mathrm{Gbps}$ (4 spatial streams, QAM-256, MU-MIMO). The maximum of the 802.11ac standard provides an output at a channel speed of up to $6.93 \mathrm{Gbps}$ with support for up to 8 spatial streams. But 8 streams will require at least 8 antennas (and preferably more) with the necessary diversity, which provides a significant increase in device size and requires more power to work via PoE.

This standard allows the use of 256-QAM modulation with coding efficiencies of $3 / 4$ and $5 / 6$, which increases the transfer rate, as well as the use of multi-user access (MU-MIMO - Multi-user MIMO) and the STA algorithm (Spanning Tree Algorithm). network tree). Also in the 802.11 ace standard the access with spatial division of channels (SDMA - Space Division Multiple Access) at which streams are divided not on frequency, and in space is applied.

Quadrature Amplitude Modulation (QAM) provides digital information stream transmission in the form of an analog signal by dividing the carrier wave into two carriers of the same frequency shifted in phase relative to each other by 900 , each of which is modulated by one of two or more discrete levels amplitude. The combination of all amplitude levels on these two carriers is a binary bit pattern.

The I and Q components are two halves of the bitstream of the digital stream that are transmitted simultaneously as voltage levels of two identical frequency carriers shifted by $90^{\circ}$ (Fig. 5). 


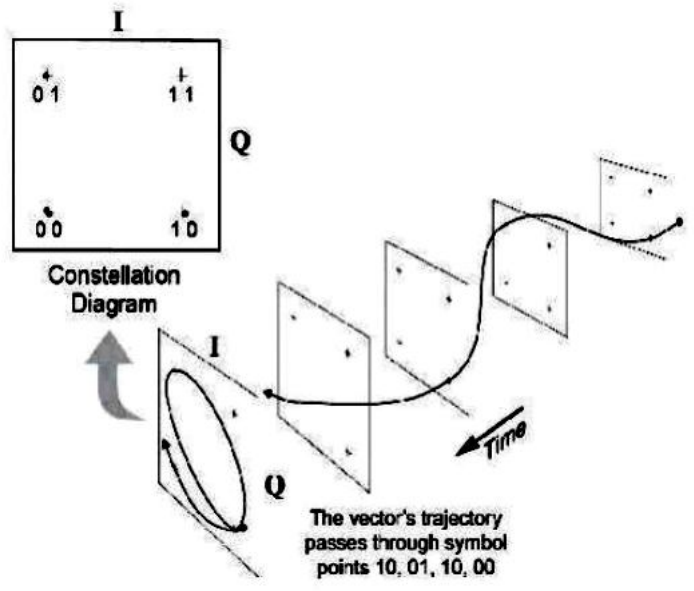

Fig. 5. The constellation diagram shows I / Q vectors. The trajectory of the vector, describing the curve in time, passes through points 10, 01, 10, 00

Component I (incident) modulates the carrier without phase shift. The Q (quadrature) component modulates the carrier with a $90^{\circ}$ offset.

Quadrature Phase Shift Keying (QPSK) is the simplest form of QAM (QAM-4 uses two carriers of the same frequency shifted by $90^{\circ}$ and two possible amplitude levels, one corresponding to zero and the other corresponding to one). Constellation - a square matrix, where the levels of amplitude I and Q components of the QAM signal, reflected as significant points in the square coordinate system I and Q.

The coordinate I determines the horizontal position of the point, and Q the vertical. The integer value of each obtained point is determined by the cell of the matrix into which it falls. The error is defined as the loss of the measured point from the cell. A QAM-16 diagram is a $4 \times 4$ matrix in which each of the 16 cells represents one of 16 possible binary combinations. The vertical and horizontal position of each point corresponds to the I and Q levels of the amplitude of the signal transmitted during one cycle (Fig. 6).

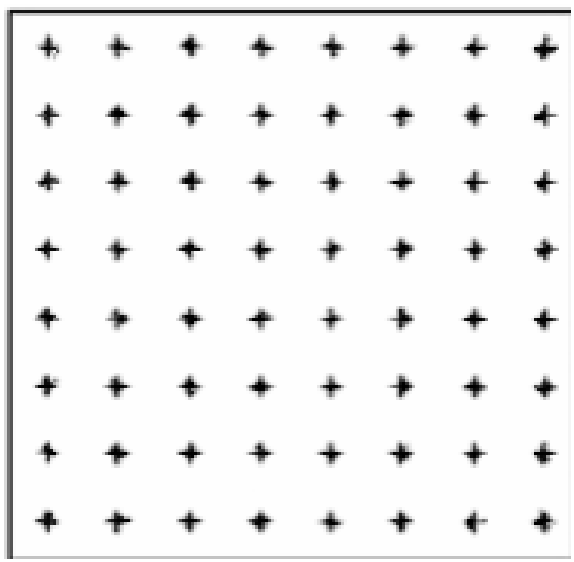

Fig. 6. Signal constellation 64-QAM

It is important to note that the last two options with eight spatial flows at this stage of technology development are unlikely for mass production and application. Moreover, the presence of three channels that do not overlap in $5 \mathrm{GHz}$ with a width of $160 \mathrm{MHz}$, each has not yet met in any country in the world. Only the FCC in the United States has come close enough to clear this part of the spectrum and provide maximum opportunities for the implementation of the solution of the Wi-Fi 802.11ac standard.

The coverage characteristics of 802.11 ac radios are much higher than $802.11 \mathrm{n}$. Although the maximum speeds of $802.11 \mathrm{ac}$ are available relatively close to the access point, the total distances for providing highspeed service are much longer than for 11 devices.

\section{Table 2 - Achievable speeds in the standard 802.11as}

\begin{tabular}{|c|c|c|c|c|c|}
\hline $\begin{array}{c}\text { Channel } \\
\text { bandwidth }\end{array}$ & $\begin{array}{c}\text { Transceiver } \\
\text { antennas }\end{array}$ & $\begin{array}{l}\text { Modulation } \\
\text { and coding }\end{array}$ & Device type & Bandwidth (individual) & $\begin{array}{l}\text { Bandwidth } \\
\text { (total) }\end{array}$ \\
\hline $80 \mathrm{MHz}$ & $1 \times 1$ & $\begin{array}{l}\text { 256-QAM 5/6, } \\
\text { short separation signal }\end{array}$ & Smartphone & $433 \mathrm{Mbps}$ & $433 \mathrm{Mbps}$ \\
\hline $80 \mathrm{MHz}$ & $2 \times 2$ & $\begin{array}{l}\text { 256-QAM 5/6, } \\
\text { short separation signal }\end{array}$ & Tablet, PC & $867 \mathrm{Mbps}$ & $867 \mathrm{Mbps}$ \\
\hline $160 \mathrm{MHz}$ & $1 \times 1$ & $\begin{array}{l}\text { 256-QAM 5/6, } \\
\text { short separation signal }\end{array}$ & Smartphone & $867 \mathrm{Mbps}$ & $867 \mathrm{Mbps}$ \\
\hline $160 \mathrm{MHz}$ & $2 \times 2$ & $\begin{array}{l}\text { 256-QAM } 5 / 6 \text {, } \\
\text { short separation signal }\end{array}$ & Tablet, PC & $1,73 \mathrm{Gbps}$ & $1,73 \mathrm{Gbps}$ \\
\hline $\begin{array}{l}160 \mathrm{MHz} \\
\text { (MU-MIMO) }\end{array}$ & $4 \times \mathrm{Tx} A \mathrm{P}$ & $\begin{array}{l}\text { 256-QAM 5/6, } \\
\text { short separation signal }\end{array}$ & $\begin{array}{l}\text { Several smart- } \\
\text { ?hones }\end{array}$ & 867 Mbps per device & $3,47 \mathrm{Gbps}$ \\
\hline $\begin{array}{l}160 \mathrm{MHz} \\
\text { (MU-MIMO) }\end{array}$ & $8 \times \mathrm{Tx} A P$ & $\begin{array}{l}\text { 256-QAM 5/6, } \\
\text { short separation signal }\end{array}$ & $\begin{array}{l}\text { Digital TV, } \\
\text { nettop, tablet, } \\
\text { PC, smartphones }\end{array}$ & $\begin{array}{l}867 \text { Mbps up to two } 1 \mathrm{x} \text { cli- } \\
\text { ents; } 1,73 \mathrm{Gbps} \text { up to one } 2 \mathrm{x} \\
\text { clients } 3,47 \mathrm{Gbps} \text { up to one } \\
4 \mathrm{x} \text { client }\end{array}$ & $6,93 \mathrm{Gbps}$ \\
\hline $\begin{array}{l}160 \mathrm{MHz} \\
\text { (MU-MIMO) }\end{array}$ & $8 \times \mathrm{T} \times \mathrm{AP}$ & $\begin{array}{l}\text { 256-QAM } 5 / 6 \text {, } \\
\text { short separation signal }\end{array}$ & $\begin{array}{l}\text { Several nettops } \\
\text { and PCs }\end{array}$ & $1.73 \mathrm{Gbps}$ to each client & $6,93 \mathrm{Gbps}$ \\
\hline
\end{tabular}




\section{Conclusions}

Intercellular diffusion, combined with MIMO technology, is the prospect of a secure communication link in the body. However, at present, the technologies we have allow us to create only a model.

Given the global interest in this topic, investment and rapid technological progress gives hope for the implementation and implementation of bio-nano technologies.

Communication systems always have many obstacles and obstacles for safe and comfortable signal transmission. Sometimes the obstacles themselves help to solve complex problems, the reflection of signals and the passage of certain obstacles that hinted at the im- plementation of the spatio-temporal distribution of the signal on which there is a partially implemented MIMO technology.

Instead of increasing the bandwidth of one channel, you can get out of the situation by increasing the number of channels and transceivers.

In cases where it is not possible to influence the transmission rate, for example in the implementation of IoBNT technologies where transmission is possible by cell diffusion, which by its nature can not give great results. We can use simpler methods to improve speed and communication in general by applying these technologies in an attempt to implement D-MIMO. This is one of the prospects for development to realize the future.

\section{REFERENCES}

1. G. V. Zvyagolska, S. N. Selevko, A. Zugbor State evaluation of Non-Stationary telecommunication system // Telecommunication and radio engineering. - Volume 66. - 2007 - Issue 3.

2. Galina Sokol, Natalia Rvachova. Dynamic system model non-standard state analyses// IEEE Second International ScientificPractical Conference «Problems of Infocommunications. Science and Technology» (PICS\&T2015). - Kharkiv. 2015.

3. Sokol G.V., Rvachova N. V., Kurchanov V.N. Mathematical model of the digital filter Kalman-Bucy in the application of non-stationary traffic // Sp-ka z o.o. «Nauka i studia» - Przemysl (Poland), 2015, Vol-10(141)

4. G.V. Sokol, O.S. Shkurupii, Computer Network Traffic Control / China News Telecommunications, 2014

5. Internet. From Wikipedia, the free encyclopedia. [Electronic resource] // - Resource access mode: https://uk.wikipedia.org/wiki/\%D0\%86\%D0\%BD\%D1\%82\%D0\%B5\%D1\%80\%D0\%BD\%D0\%B5\%D1\%82

6. Shcho take Internet - korotkyi likbez pro Vsesvitniu pavutynu. [Electronic resource] // - Mode of access to the resource: dzudzylo.com/tsikavo/shho-take-internet-korotkyj-likbez-pro-vsesvitnyu-pavutynu.html

7. Lektsiia 1. Zahalni poniattia Internetu rechei. Boreiko Oleh Yuriiovych. [Electronic resource] - Resource access mode: http://academicfox.com/lektsiya-1-zahalni-ponyattya-internetu-rechej/

8. Ozgur B. Akan On the Physical Design of Molecular Communication Receiver Based on Nanoscale Biosensors / Murat Kuscu, Ozgur B. Akan // 28 Mar 2016.

9. Slyusar' I.I. Analiz tekhnolohii IoBNT / I.I. Slyusar, V.I. Slyusar, P.A. Podhornyy // Abstracts of the 71st scientific conference of professors, teachers, researchers, graduate students and students of the university. - Poltava: PoltNTU, 2018. - T. 1.

10. Seyed Mohammadreza Rouzegar Diffusive MIMO Molecular Communication Systems / Seyed Mohammadreza Rouzegar, Prof. Umberto Spagnolini // July 2017.

11. Seyed Mohammadreza Rouzegar Diffusive MIMO Molecular Communication Systems / Seyed Mohammadreza Rouzegar, Prof. Umberto Spagnolini // July 2017.

12. MIMO - Miltiple Input Multiple Output. Resource access: http://anisimoff.org/lte/general/mimo.html.

13. Seyed Mohammadreza Rouzegar Diffusive MIMO Molecular Communication Systems / Seyed Mohammadreza Rouzegar, Prof. Umberto Spagnolini // July 2017

Received (Надійшла) 23.09.2020

Accepted for publication (Прийнята до друку) 28.10.2020

\section{Перспективи застосування МIMO на основі IEEE 802.11ас в технологіях IOT}

\section{Г. В. Сокол, П. А. Подгорний, А. С. Міщенко, Р. В. Пісковий, Д. О. Герасимов}

Анотац ія. Вимоги до мережі рівень трафіку Інтернет стають все більш вибагливі. Від стандартного підключення кабелем зі швидкістю 100 Мбіт/с до використання Wi-Fi зі швидкістю до 2,3 Гбіт/с на канал 160 МГц (802.11ас2) з одночасним забезпеченням режиму множинного входу - множинного виходу з кількома користувачами (Multi User Multiple Input Multiple Output, MU-MIMO). Крім того, впровадження систем мобільного зв' язку 5G дозволило значно підвищити рівень трафіку мобільного Інтернету. В світі вже почались розробки наступного покоління 6G зі швидкостями від 100 Гбіт/с до 1 Тбіт/с при управлінні мережі штучним інтелектом, яке планують на 2026-30 pр. В свою чергу, розширення номенклатури сервісів на базі хмарних обчислень дало значний поштовх до розвитку нових напрямків застосування Інтернету. Як наслідок, швидко впроваджуються різноманітні концепції на основі Інтернету речей (Internet of Things, IоT). Як відомо, такий підхід надає можливість підключення до Інтернету будь-якого об'єкту, оснащеного датчиками або сенсорами, що можуть отримувати, передавати та обробляти інформацію, і виконувати певні дії в залежності від отриманої інформації. В якості прикладів можна вказати «розумний будинок», «розумне місто», та ін. Реалізація зв’язку між об’єктами можлива через Інтернет з використанням технологій Bluetooth, Wi-Fi, ZigBee та ін. Ще одним, досить новим напрямком $\epsilon$ концепція Інтернету біонаноречей (Internet of BioNanoThings, IoBNT). Як відомо, жива клітина - вже $\epsilon$ своєрідною наномашиною яка керується генетичною програмою. Процесором і пам’яттю виступає ядро клітини, мітохондрії служать батарейкою а білки-рецептори на поверхні цієї клітини - це сенсори, які можуть сприймати сигнали, а їх щілинні контакти з іншими клітинами, можуть відправляти сигнали. Залишається лише перепрограмувати їх для свої потреб. При цьому, потрібно ще організувати зв'язок не тільки між самими клітинами, але і з мережею Інтернет. Клітина може передавати побітову інформацію в залежності від стану, але з дуже низькою швидкістю. Одним 3 варіантів реалізації комунікацій може стати МIMO.

Ключов і слов а: Інтернет, Інтернет речей, Інтернет біонано речей, MIMO, Wi-Fi, QAM 